DOI: https://doi.org/10.36477/tourismhospcee-1-3

УДК 614.2:615.1:658

Братішко Ю. С.

кандидат фармацевтичних наук, доцент, доцент кафедри управління, економіки та забезпечення якості у фармації Національного фармацевтичного університету ORCID: https://orcid.org/0000-0002-3831-8722

Посилкіна О. В.

доктор фармацевтичних наук, професор, професор кафедри управління, економіки та забезпечення якості у фармації Національного фармацевтичного університету ORCID: https://orcid.org/0000-0003-4529-4332

Деренська Я. М. кандидат економічних наук, доцент, доцент кафедри управління, економіки та забезпечення якості у фармації Національного фармацевтичного університету ORCID: https://orcid.org/0000-0001-7428-6249

Bratishko Yuliia, Posilkina Olga, Derenskaya Yana National University of Pharmacy

\title{
ПРИНЦИПИ ПОБУДОВИ КОНЦЕПТУАЛЬНОЇ МОДЕЛІ СОЦАЛЬНОЇ ВІДПОВІДАЛЬНОСТІ У ФАРМАЦІЇ
}

\section{PRINCIPLES OF CONSTRUCTION OF CONCEPTUAL MODEL OF SOCIAL RESPONSIBILITY IN PHARMACY}

\begin{abstract}
Стаття присвячена розробиі засад управління соціально відповідальною діяльністю фармацевтичних компаній як найважливішої умови підвищення якості, ефективності та доступності фармацевтичного забезпечення населення. Визначені специфічні характеристики існуючої національної моделі сочіальної відповідальності бізнесу. Визначено, що українська модель об 'єднує сучасний світовий досвід формування корпоративної соціальної відповідальності та відображає концептуальні спрямування ії подальшого розвитку згідно з вимогами міжнародних стандартів. Обгрунтовані основні методологічні принципи побудови концееттальної моделі сочіальної відповідальності фармацевтичного бізнесу в умовах розвитку глобалізаичійних та інтеграційних процесів і необхідності імплементації вимог міжнародних стандартів, щзо регламентують сочіально відповідальну діяльність.
\end{abstract}

Ключові слова: корпоративна сочіальна відповідальність; сочіальна відповідальність фармачевтичного бізнесу; фармачевтична компанія; фармачія.

Статья посвящена разработке принциипов управления соичиально ответственной деятельностью фармацевтических компаний как важнейтего условия повышения качества, эффективности и доступности фармацевтического обеспечения населения. Определены специфические характеристики существующей национальной модели социильной ответственности бизнеса. Определено, что украинская модель объединяет современный мировой опьт формирования корпоративной соииальной ответственности и отражает концептуальные направления дальнейшего развития в соответствии с требованиями мељдународных стандартов. Обоснованы основные методологические принцииы построения концептуальной модели социальной ответственности фармацевтического бизнеса в условиях развития глобализационных и интеграционных проиессов и необходимости имплементации требований международных стандартов, регламентируюших сочиально ответственную деятельность.

Ключевые слова: корпоративная сочиальная ответственность; социальная ответственность фармаиеевтического бизнеса; фармацевтическая компания; фармация.

The article is devoted to the development of theoretical, methodological and scientific-practical foundations for managing the socially responsible activities of domestic pharmaceutical companies as the most important condition for improving the quality, efficiency and accessibility of pharmaceutical supply to the population, which becomes especially relevant in the context of the global pandemic, closing state borders and disrupting the business ties of domestic pharmaceutical companies with foreign partners. In addition, the introduction of approaches and tools of 
socially responsible management in the activities of domestic pharmaceutical companies will contribute to the growth of their investment attractiveness and improvement of business reputation, which will positively affect the increase in their competitiveness in both the domestic and external pharmaceutical markets. Specific characteristics of the existing national model of social responsibility of business, which was formed under the influence of European integration processes taking place today, are determined. It is determined that this model combines the modern world (European, American, Asian) experience in the formation of corporate social responsibility and reflects the conceptual directions of its further development in accordance with the requirements of international standards. It was determined that the Ukrainian model of social responsibility is currently almost completely focused on ensuring the basic level of corporate social responsibility of economic entities, which consists in a clear (mandatory) compliance with the existing national legislation in the field of quality, compliance with tax, environmental, labor legislation, legislation in the field of higher education and health care, but all that is «beyond» this basic level, that is, what is «voluntary», companies implement of their own choice. The main methodological principles of building a conceptual model of social responsibility of the pharmaceutical business in the context of the development of globalization and integration processes and the need to implement the requirements of international standards governing socially responsible activities are justified. It has been proved that the most important methodological principle of building a modern system adapted to international standards of social responsibility of the pharmaceutical business in Ukraine is the understanding of the need for its integration into the system of social responsibility in the country. Foreign and domestic experience of management of social responsibility of pharmaceutical companies has been investigated.

Keywords: corporate social responsibility; social responsibility of the pharmaceutical business; risks associated with socially responsible activities; Social and Corporate Responsibility Manager; state regulation of social responsibility of pharmaceutical business; pharmaceutical company; pharmacy.

Постановка проблеми. В умовах розвитку глобалізаційних та інтеграційних процесів, становлення мережевої економіки і суспільства знань, стрімкого розширення та ускладнення взаємозв'язків національних господарств і людей, зростання їх взаємозалежності особливої уваги набуває проблема соціально відповідального функціонування бізнесу, у т.ч. на основі запровадження міжнародних стандартів соціальної відповідальності (СВ).

Пандемія коронавірусної хвороби (COVID-19) також суттєво вплинула на зміну поглядів щодо пріоритетів діяльності компаній у всьому світі. Глобальна фармацевтична галузь одна 3 перших відчула наслідки закриття економіки Китаю, на який припадає близько 40\% світового виробництва активних фармацевтичних інгредієнтів (АФI), та інших країн постачальників сировини. Закриття кордонів і режим тривалого карантину створили суттєві загрози не тільки в ланцюжку постачань для фармацевтичних виробників, а i серйозно вплинули на ефективність функціонування фармації в цілому. Відбулося зниження продажів рецептурних лікарських засобів (ЛЗ), що ускладнює виведення нових препаратів і стимулює зміни в дистрибуційній системі. Дослідницька діяльність фармацевтичних компаній (ФК) у напрямках, не пов'язаних із COVID-19, істотно сповільнилася під впливом пандемії. Більшість клінічних досліджень довелося призупинити через обмеження карантину, що сповільнює виведення нових лікарських препаратів на ринок. Отже, пандемія порушила нормальне функціонування всіх складових вітчизняної фармації i загострила проблему доступності для населення якісної фармацевтичної допомоги. Ситуація, яка сьогодні склалася у вітчизняній і світовій фармації, повинна стати серйозним поштовхом для повного переосмислення філософії діяльності ФК, які в ці важкі часи повинні нарешті усвідомити велику власну СВ, та почати вибудовувати діяльність більш прозоро, відкрито, інноваційно спрямовано та соціально турботливо. Лише дії ФК, як соціально відповідальних організацій, будуть створювати надію на виживання не тільки окремих компаній, але й вітчизняної фармації в цілому, а відповідно і збереження здоров'я населення України.

Аналіз останніх досліджень і публікацій. Дослідженнями різних аспектів управління соціально відповідальною діяльністю (СВД) суб' єктів фармацевтичного ринку (СФР) займалися такі науковці: Галій Л., Громовик Б., Свтушенко О., Зарічкова М., Кабачна А., Книш С., Котвіцька А., Мнушко 3., Немченко А., Посилкіна О., Слободянюк М., Ткаченко Н., Толочко В., Артюх Т., Волкова А., Суріков О., Червоненко Н., Черкашина А., Чмихало Н. та ін. Але, незважаючи на значний науковий наробок цих вчених, не вирішеними залишаються питання формування, організаційного забезпечення, оцінки та розвитку системи соціальної відповідальності фармацевтичного бізнесу (СВФБ).

3 огляду на зростаючу роль в умовах сьогодення СВД ФК у всьому світі, а також для пошуку шляхів вирішення існуючих проблем щодо СВФБ актуальними є дослідження щодо розробки методологічних, методичних i науково-практичних засад побудови системи управління СВД СФР. Вищезазначене зумовило актуальність теми, мету, завдання, структуру та логічну побудову дисертаційних досліджень.

Мета і завдання дослідження. Метою дисертаційної роботи є розробка теоретичних, методичних і науково-практичних засад управління СВД ФК в Україні для зростання соціальної спрямова- 
ності їх діяльності, інвестиційної привабливості і конкурентоспроможності, що сприятиме підвищенню якості, ефективності і доступності фармацевтичного забезпечення населення України.

Для досягнення поставленої мети необхідно було вирішити такі завдання:

- обгрунтувати методологічні принципи і наукові підходи до побудови системи СВФБ:

- запропонувати концептуальну модель системи СВФБ в Україні, визначити загальну методику дисертаційної роботи та методи досліджень.

Наукова новизна отриманих результатів полягає в обгрунтуванні нових та поглибленні існуючих теоретичних і науково-практичних підходів, що спрямовані на розв'язування актуальної наукової проблеми - розробку методологічних і методичних засад побудови системи СВ у фармації на різних рівнях управління, в основу якої покладено розуміння необхідності збалансування інтересів споживачів ЛЗ, ФК та аптечних закладів, суспільства і держави для підвищення доступності ЛЗ i надання пацієнтам належної фармацевтичної допомоги, з одного боку, і створення умов для сталого розвитку СФР, з іншого.

Уперше:

- введено до наукового обігу категорії «соціальна відповідальність фармацевтичного бізнесу», «концепція соціальної відповідальності фармацевтичного бізнесу», «сталий соціально-економічний розвиток фармацевтичних підприємств»;

- побудовано концептуальну модель СВФБ, визначені іiі складові, що дозволяє усвідомити унікальність та багатоаспектність СВД СФР, зважаючи на соціальну значимість фармації;

Набуло подальшого розвитку:

- змістовне наповнення концепції КСВ ФК;

- рівнева модель СВ кожної окремої ФК, яка дозволяє наглядно уявити етапи крокування компанії до статусу соціально відповідальної організації;

В умовах екзистенційної кризи, яка проникла сьогодні у всі сфери життя суспільства, сенс функціонування фармацевтичних компаній (ФК) докорінно змінюється. На перший план виходять проблеми забезпечення довготривалого та стабільного функціонування ФК як в Україні, так i всьому світі, що є однією з найважливіших умов збереження здоров'я і життя людей. Це в значній мірі може бути забезпечено за рахунок лояльності споживачів, партнерів по бізнесу, персоналу і є запорукою прогнозованості попиту на продукцію ФК. Саме тому питання СВ, створення позитивного ділового іміджу, підвищення репутації ФК як відповідального роботодавця, відповідального платника податків, відповідальної «екофредлі» компанії та ефективне позиціювання ФК в інформаційному середовищі на сьогодні є такими важливими. Це й обумовило вибір нами напряму дисертаційного дослідження, що , з одного боку, пов'язано з великою актуальністю цієї тематики, а з іншого - відсутністю науково обгрунтованого концептуального розуміння СВФБ у сучасних ринкових умовах.

Розпочинаючи аналіз феномену КСВ як актуального явища розвитку фармацевтичного бізнесу, необхідно звернутися до його витоків, що сприятиме формуванню і подальшому розвитку методологічних основ концепції СВФБ.

Аналіз еволюції теорій щодо розуміння сутності та змістових характеристик КСВ показує, що протягом декількох десятиліть вчені розробляли й удосконалювали цю концепцію (рис. 1), що і створює теоретичну основу побудови сучасної системи СВФБ.

Найважливішим методологічним принципом побудови сучасної, адаптованої до міжнародних стандартів системи СВФБ, є розуміння необхідності ії інтеграції в систему СВ в країні. До того ж необхідним $є$ формування модельної бази СВФБ $з$ урахуванням національних особливостей та наявних соціально-економічних умов функціонування ФК в Україні. Нами визначені специфічні характеристики національної моделі $\mathrm{CB}$, які сформувалися під впливом євроінтеграційних процесів, що відбуваються сьогодні в Україні (рис. 2).

Дана модель об'єднує сучасний світовий (європейський, американський, азійський) досвід формування КСВ та відображає концептуальні спрямування ïi подальшого розвитку згідно з вимогами міжнародних стандартів. Наведена модель дає розуміння рівня КСВ та іiі напрямків, які сформувались на сьогодні в Україні. Тобто українська модель СВ на даний час майже повністю зорієнтована на забезпечення базового рівня КСВ, який полягає у чіткому (обов'язковому) дотриманні чинного національного законодавства у сфері якості, дотриманні податкового, екологічного, трудового законодавства, законодавства у сфері вищої освіти та охорони здоров'я, але все що «понад» цього базового рівня, тобто те, що $є$ «добровільним», ФК реалізують за власним вибором.

Національною особливістю $є$ те, що сьогодні деякі вітчизняні ФК виявляють бажання мати чіткі інструкції до реалізації соціально відповідальної

діяльності, бо вони звикли виконувати чіткі інструкції держави, міністерств та відомств у своій поточній діяльності, тому і на цю сферу функціонування ними переноситься такий самий підхід. А СВ за своєю природою є індивідуальною для кожної ФК. Свій неохочий перехід до реалізації програм додаткової СВ вітчизняні ФК найчастіше пояснюють відсутністю достатнього фінансового потенціалу та бажанням забезпечити фінансово міцну поточну діяльність. До то ж на теперішній час довгострокові інноваційні та соціальні проєкти українськими ФК реалізуються фрагментарно. Але тут існує значне протиріччя 


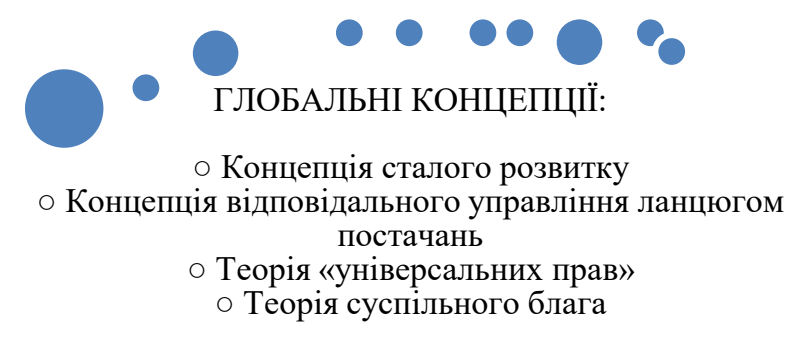

ГЕОГРАФІЧНІ КОНЦЕПЦІї:

○ Теорія корпоративного егоїзму

- Теорія корпоративного альтруїзму

о Теорія розумного егоїзму

○ Теорія корпоративного конституціоналізму

○ Теорія суспільного договору

○ Теорія корпоративного громадянства

○ Теорія соціального трипартизму о Концепція етики

○ Концепція зацікавлених сторін (стейкхолдерів)

○ Концепція соціальних вимог

○ Концепція обов'язків

○ Концепція економічної відповідальності

(інструментальні теорії: теорія максимізації

акціонерної вартості, теорія конкурентних переваг,

теорія маркетингу соціально значимої проблеми

(соціального маркетингу)

○ Сиигнальна (репутаційна) теорія

○ Теорія достатності / недостатності ресурсів ○ Теорія опортунізму

○ Теорія синергетичної дії

○ Інтегративні теорії (менеджмент непередбачуваних

ситуацій, концепція соціального реагування, теорія корпоративної соціальної діяльності)
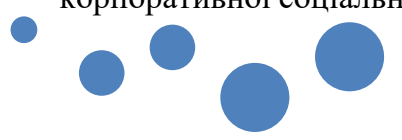

Рис. 1. Сукупність теорій корпоративної соціальної відповідальності, які утворюють теоретичне підгрунтя формування сучасної концепції соціальної відповідальності фармацевтичного бізнесу

Джерело: узагальнено на підставі [1-11]

між причинами та наслідками. У вітчизняних ФК недостатньо розвинута соціально відповідальна діяльність через брак фінансових ресурсів, чи навпаки - існує брак фінансових ресурсів через в середньому низьку додаткову соціальну відповідальність українських ФК? Якщо змінити акценти 3 того, що $є$ первинним, а що вторинним, то і розуміння значення КСВ приходить само собою. Постулатом для ФК має стати позиція: щоб бути інвестиційно привабливою, конкурентоспроможною компанією із бездоганною репутацією завтра необхідно бути соціально відповідальною ФК вже сьогодні.

Проведені нами дослідження дозволили визначити наукові принципи, на які повинна опиратися система управління СВФБ в Україні, зважаючи на загальносвітові тенденції і вимоги міжнародних стандартів:

1) принцип дії на засадах абсолютної добровільності - тобто ФК мають самостійно, без від- чуття зовнішнього тиску повністю прийняти бізнес позицію функціонування на благо суспільства, не тому, що цього вимагають зовнішні фактори, а тому, що вони самі розуміють величезну силу впливу власної діяльності на людство;

2) комплексність - тобто ФК повинні бути соціально відповідальними у всіх сферах, як зовнішній, так і внутрішній. Не допустимо, наприклад, бути відповідальним перед споживачами за якість, цінову та фізичну доступність ЛЗ і одночасно нехтувати соціальними інтересами персоналу, досягаючи зниження собівартості продукції за рахунок зниження заробітної плати або не надаючи йому конкурентного соціального пакету, або перевантажуючи персонал;

3) системність - тобто ФК як соціально відповідальні організації, повинні розуміти взаємозв'язок соціально відповідальної, господарської, фінансової, інноваційної, інвестиційної, маркетингової, логістичної складової власної діяльності, як 


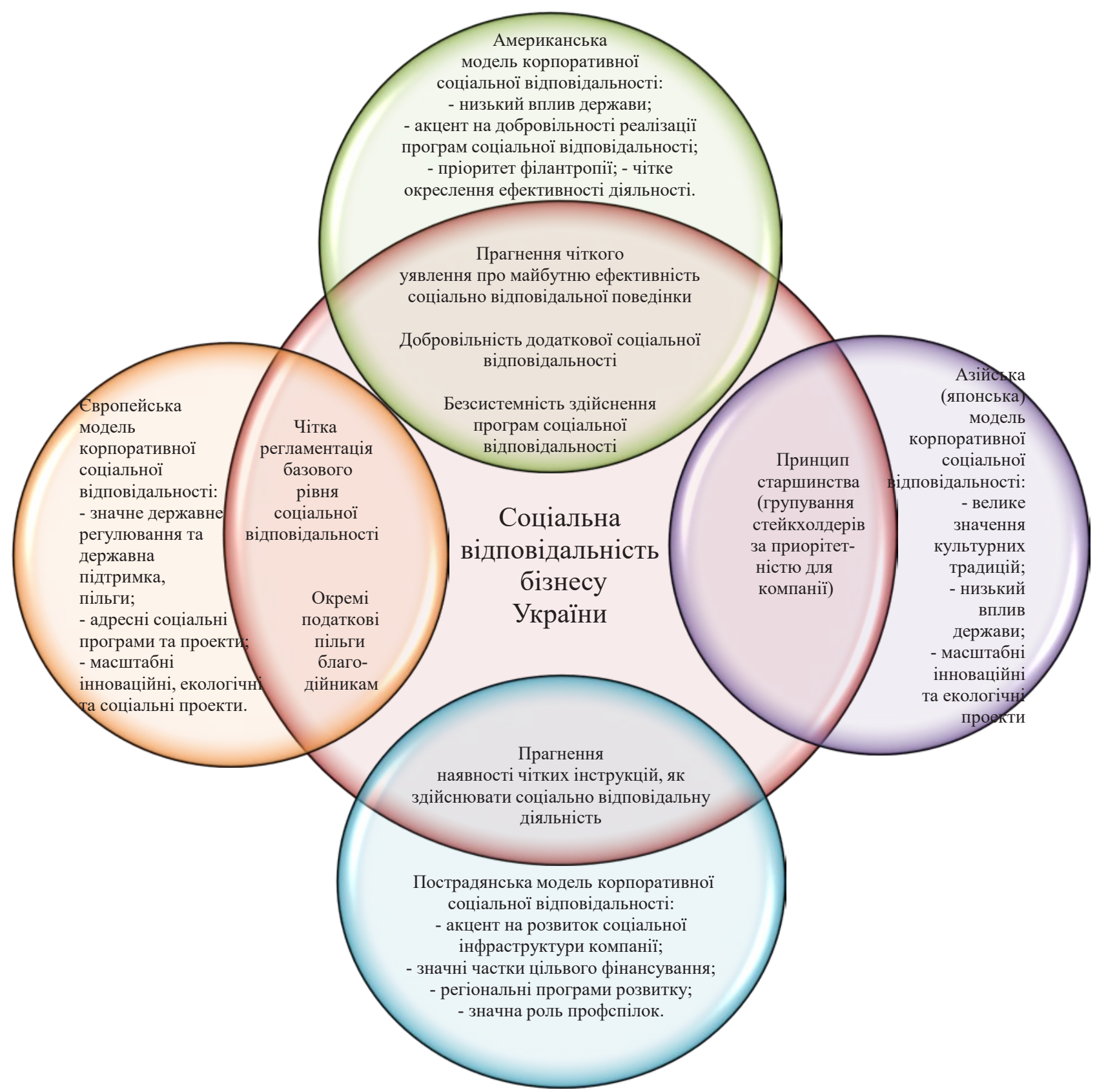

Рис. 2. Характеристика особливостей національної моделі соціальної відповідальності

Джерело: власна розробка

єдиної цілісної системи, «системного організму», 3 якого неможливо вичленити якийсь окремий напрям, не зачіпаючи інший;

4) перманентність - не просто довготривала, а постійна, стабільна реалізація ФК соціально відповідальних проектів та програм;

5) вагомість - інвестування достатніх ресурсів ФК у власний соціально-інноваційний розвиток;

6) відкритість, прозорість та публічність - повне розкриття та активне розповсюдження інформації про напрямки соціально відповідальної діяльності ФК шляхом регулярного ініціативного складання соціальної (нефінансової) звітності і представлення компанії в інформаційному середовищі, ведення корпоративного дайджесту, тісна взаємодія із засобами масової інформації, інфлюенсерами, активне представлення компанії та результатів іiі соціально відповідальної діяльності у соціальних мережах;

7) адресність соціальної підтримки - всю соціально відповідальну діяльність, соціальні програми та проекти ФК повинні надавати конкретній групі стейкхолдерів, або навіть окремій особі. Соціальна підтримка повинна здійснюватися за критерієм «від кого» і «до кого», тоді ФК мають змогу досліджувати її ефективність завдяки прослідковування шляху цих дій та заходів;

8) різноманітність форм, методів та напрямів реалізації - тобто ФК повинні самостійно обирати 
інструменти здійснення соціально відповідальної діяльності серед будь яких доступних їм, та можуть у будь який спосіб їх комбінувати, змінювати їх перелік, модернізувати, удосконалювати, пристосовувати, виходячи із власних цілей, власного потенціалу та спрямовувати їх на обраних стейкхолдерів;

9) самоаналіз та самоаудит - під час здійснення соціально відповідальної діяльності ФК повинні безперервно проводити моніторинг власної діяльності, який сприяє отриманню актуальної інформації про стан іiі реалізації та дозволяє вчасно діагностувати проблеми;

10) самостандартизація - тобто, керуючись міжнародними стандартами, рекомендаціями, положеннями, ФК повинні самостійно розробляти власну політику у сфері КСВ, крокуючи шляхом постійного вдосконалення власної діяльності;

11) принцип партнерської взаємної вигоди один із основоположних принципів КСВ, який дає розуміння, що соціальна відповідальність не $\epsilon$ «грою в одні ворота». ФК, які вирішили йти шляхом соціально відповідальної діяльності, отримують великий спектр зисків, які торкаються довготривалого, стратегічного забезпечення власної конкурентоспроможності, інвестиційної привабливості, інноваційного соціально-економічного сталого розвитку. Тобто розуміння того що реалізація моделі СВФБ - це вигідно для всіх учасників цього процесу, бо внаслідок її реалізації ФК здатні підвищити власну соціально-економічну ефективність (збільшення результативності фінансовогосподарської діяльності за рахунок підвищення лояльності споживачів, лікарів, пацієнтів; стабільність поточного забезпечення діяльності за рахунок розвитку партнерських відносин із постачальниками фармацевтичної сировини та субстанцій; збільшення ефективності управління фармацевтичним персоналом за рахунок підвищення його лояльності та зміцнення корпоративної культури; збільшення надходжень інвестиційного капіталу за рахунок укріплення партнерських відносин із фінансово-кредитними установами, інвестиційними фондами, приватними акціонерами; збільшення ефективності інноваційної діяльності за рахунок партнерства із науковими установами, закладами вищої освіти, лабораторіями та базами клінічних досліджень; підвищення державної та регіональної підтримки за рахунок зміцнення приватно-державного партнерства; формування гідної ділової репутації). Хоча і у довгостроковому періоді, але ці мотиви $є$ принциповими для визначення безальтернативної необхідності для ФК бути ще більш соціально відповідальними;

12) антикорупційний принцип - ФК повинні діяти чесно, відкрито, прозоро і лише у межах правового поля, викорінюючи явище корупції як у національному, та к і у глобальному масштабі;
13) принцип доброчесної конкуренції - ФК повинні діяти у відповідності да антимонопольного законодавства, бути максимально чемними по відношенню до конкурентів, діяти лише у межах правового поля, викорінюючи явище економічного шпіонажу.

14) принцип консолідованої соціальної відповідальності, який полягає в розумінні всіма ФК того, що лише за умов дотримання всіма суб' єктами фармацевтичної галузі базового рівня CB в країні можна побудувати ефективну і відповідну вимогам міжнародних стандартів систему фармацевтичного забезпечення населення.

Виходячи з означених методологічних принципів нами побудована концептуальна модель СВФБ в нових умовах господарювання: розвитку глобалізаційних та інтеграційних процесів, наслідком яких стає в т.ч. і загроза пандемій, певної вичерпаності (обмеженості) ресурсів, інформатизації суспільства і цифровітизації економіки , зростання ролі людського капіталу в умовах загострення конкурентної боротьби не тільки між окремими компаніями, а між державами тощо (рис. 3).

У моделі номерами проставлені визначені нами методологічні принципи побудови системи СВФБ. Завдяки реалізації зазначених наукових принців будь який СФР у власній соціально відповідальній еволюції має пройти певні етапи розвитку: від відповідального фармацевтичного виробника (рівень відповідальності перед споживачами, пацієнтами, лікарями, фармацевтами, провізорами), постачальника фармацевтичної сировини та субстанцій, відповідального надавача фармацевтичної допомоги до відповідального суб'єкта, який діє у межах правового поля (рівень відповідальності перед державою, місцевою владою, контролюючими органами, інвесторами, фінансово-кредитними установами, місцевим співтовариством, засобами масової інформації, суспільством в цілому), потім до відповідального бізнес партнера та роботодавця (рівень відповідальності перед персоналом, акціонерами, власниками, постачальниками, конкурентами), потім до відповідального інноватора, активного учасника інноваційного розвитку шляхом впровадження інноваційних Л3, проводячи відповідні наукові дослідження (рівень відповідальності перед суспільством, науковими установами, закладами вищої професійної освіти), до соціально відповідальної компанії, яка добровільно взяла на себе додаткові зобов'язання перед прийдешніми поколіннями.

Тому CB має бути адитивною з огляду на формування ефективного ланцюга фармацевтичного забезпечення населення, тобто має складатися із: CB фармацевтичного персоналу (особистісний рівень (нанорівень) СВ); СВ окремої ФК (мікрорівень соціальної відповідальності - фармацевтичні виробники, підприємства-виробники субстанцій, 


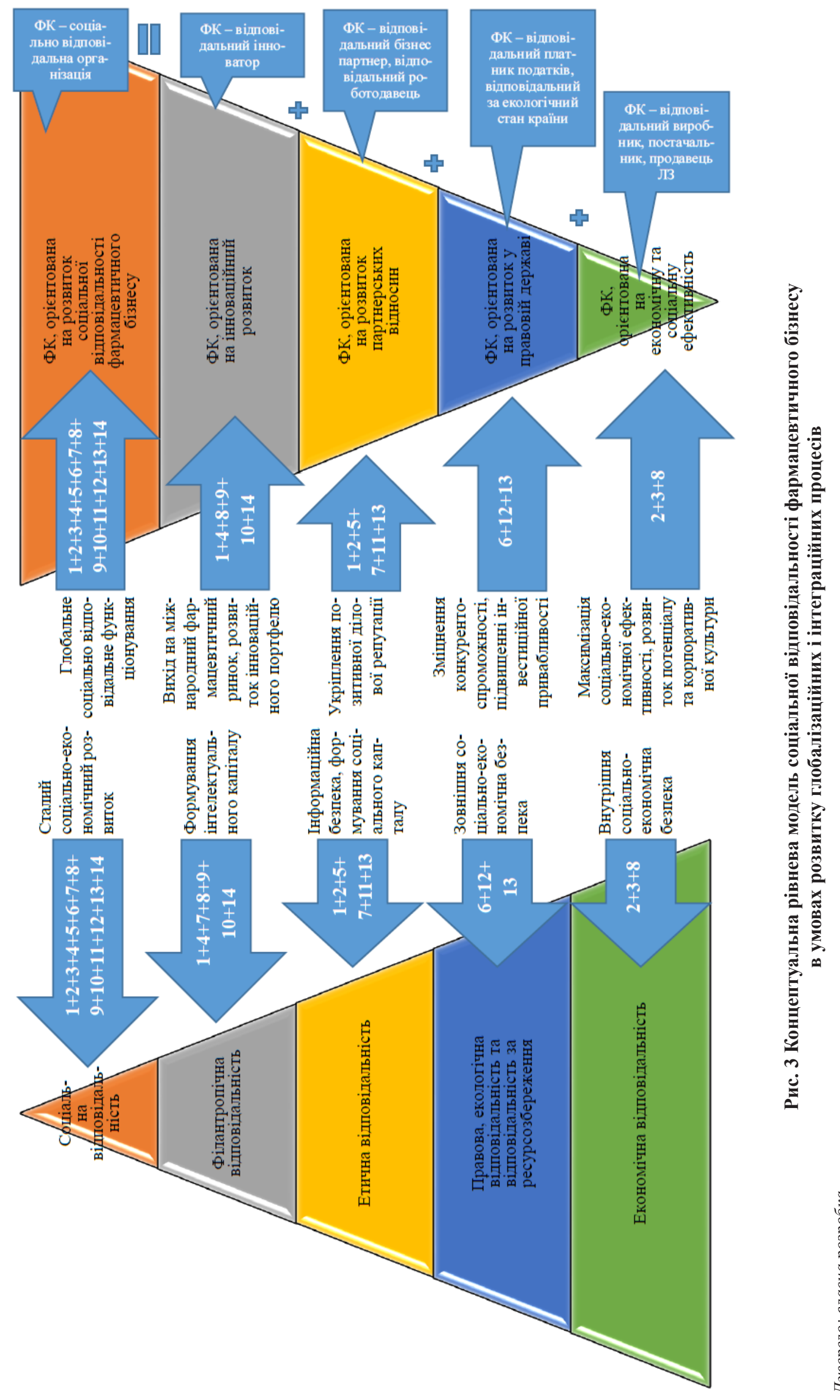


ветеринарних препаратів, лікувальних косметичних засобів, дієтичних добавок тощо; підприємства, які здійснюють оптову та роздрібну реалізацію цієї продукції; наукові заклади, які виконують науково-дослідні та дослідно-конструкторські розробки зі створення нових ЛЗ, технологічних процесів, обладнання та методів контролю якості; навчальні заклади, які здійснюють підготовку та перепідготовку фахівців для потреб галузі, а також організації та установи, які формують і реалізують інформаційно-аналітичне забезпечення діяльності компаній); СВ керівників системи охорони здоров'я на регіональному рівні, професійних громадських організацій, закладів охорони здоров'я і ФК, які діють на визначеній території (мезорівень); СВ фармацевтичного сектору галузі охорони здоров'я в цілому (галузевий рівень відповідальності) - керівних органів системи охорони здоров'я (фармації) i персональної відповідальності керівників галузі і громадських професійних (за фармацевтичним профілем) організацій; СВ держави в цілому (макрорівень); глобальної СВФБ (мегарівень).

Тому важливо зрозуміти, що СВ як явище може існувати лише у вільному середовищі і можлива лише для вільних у своїх діях суб'єктів, які при цьому неухильно і свідомо дотримуються закону, прав людини, норм поведінки, етики та моралі, $€$ солідарними, постійно узгоджують інтереси зі всіма стейкхолдерами, функціонують на засадах чесності, відкритості, прозорості, підзвітності та піклуються про наслідки власної діяльності для суспільства і, що особливо важливо, для майбутніх поколінь. Проаналізований досвід управління СВ у вітчизняних та закордонних ФК, в наслідок чого визначено сутнісні характеристики національної моделі $\mathrm{CB}$, які сформувалися під впливом євроінтеграційних процесів, що відбуваються сьогодні в Україні. Визначені напрями СВФБ, що дозволило усвідомити унікальність та багатоаспектність СВД СФР, особливо враховуючи соціальну значимість фармації, і обумовило необхідність розробки i впровадження адаптованих до специфіки галузі підходів до управління СВ. Обгрунтовані методологічні принципи і наукові підходи до формування адекватної сучасним умовам і вимогам міжнародних стандартів концептуальної рівневої моделі СВФБ, яка дозволяє визначити напрями руху ФК до статусу соціально відповідальних організацій.

\section{Список використаних джерел:}

1. Антошко Т. Р. Основи впровадження корпоративної соціальної відповідальності на промислових підприємствах України. Інноваційна економіка. 2011. № 4(23). С. 297-305.

2.Благов Ю. Е. Генезис концепции корпоративной социальной ответственности. Вестник Cанкт-Петербургского университета. 2006. № 2. С. 3-24.

3. Бутко М. Генезис соціальної відповідальності бізнесу та її становлення в Україні. Економіка України. 2009. № 7. C. 74-85.

4. Ворона О. В. Методичні підходи до оцінки рівня соціальної відповідальності. Вісник економіки транспорту і промисловості. 2010. № 30. С. 127-133.

5. Грицина Л. А. Еволюція та формування концепції корпоративної соціальної відповідальності підприємства. Наука та технологї: крок в майбутнє - 2007 : тези допов. міжнар. наук.-практ. конф. Дніпропетровськ : Наука та освіта, 2007. Т. 2. С. 30-36.

6. Дейч М. С., Новікова О. Ф. Глобальні стратегії сталого розвитку та соціальна відповідальність України за їх реалізацію. Вісник Тернопільського національного економічного університету. 2011. Вип. 5-2. С. $297-303$.

7.Никифорова Л. А. Корпоративна соціальна відповідальність бізнесу: історичний огляд світового досвіду. Торгівля і ринок України : темат. зб. наук. пр. / гол. ред. О. О. Шубін. Донецьк : ДонНУЕТ, 2010. Вип. 29. С. 73-79.

8. Олійник О. Р. Міжнародний досвід розвитку соціальної відповідальності та можливість його застосування в Україні. URL: http://nbuv.gov.ua/UJRN/inek_2015_4_7 (дата звернення: 20.11.2020).

9. Піроженко Н. Феномен соціальної відповідальності бізнесу: теоретичний та історичний аспекти. URL: http://www.nbuv.gov.ua/portal/Soc_Gum/Apdu_o/2009_1/R_2/Pirogenko.pdf (дата звернення: 20.11.2020).

10.Соціальна відповідальність: теорія і практика розвитку : монографія / А. М. Колот та ін. ; за наук. ред. д-ра екон. наук, проф. А. М. Колота. Київ : КНЕУ, 2012. 501 с.

11. Супрун Н. А. Концептуальні засади корпоративної соціальної відповідальності. Корпоративна соиіальна відповідальність бізнесу та освіти: досвід та проблеми розвитку : ЛІ УАРМБО-2013. Черкаси, 2013. С. 43.

\section{References:}

1. Antoshko T. R. (2011) Osnovi vprovadzhennya korporativnoï social'noi vidpovidal'nosti na promislovih pidpriemstvah Ukraini. Innovacijna ekonomika. 2011, no. 4(23), pp. 297-305.

2.Blagov Yu. E. (2006) Genezis koncepcii korporativnoj social'noj otvetstvennosti. Vestnik Sankt-Peterburgskogo universiteta, no. 2, pp. 3-24.

3. Butko M. (2009) Genezis social'noi vidpovidal'nosti biznesu ta ii stanovlennya v Ukraini. Ekonomika Ukraini, no. 7 , pp. $74-85$.

4. Vorona O. V. (2010) Metodichni pidhodi do ocinki rivnya social'noi vidpovidal'nosti. Visnik ekonomiki transportu i promislovosti, no. 30, pp. 127-133. 
5. Gricina L. A. (2007) Evolyuciya ta formuvannya koncepcii korporativnoï social'noi vidpovidal'nosti pidpriєmstva. Nauka ta tekhnologii: krok v majbutne - 2007: tezi dopov. mizhnar. nauk.-prakt. konf. Dnipropetrovs'k: Nauka ta osvita, t. 2, pp. 30-36.

6. Dejch M. E., Novikova O. F. (2011) Global'ni strategii stalogo rozvitku ta social'na vidpovidal'nist' Ukraini za ih realizaciyu. Visnik Ternopil's'kogo nacional'nogo ekonomichnogo universitetu, vol. 5-2, pp. 297-303.

7. Nikiforova L. A. (2010) Korporativna social'na vidpovidal'nist' biznesu: istorichnij oglyad svitovogo dosvidu. Torgivlya i rinok Ukraini: temat. zb. nauk. pr. / gol. red. O. O. Shubin. Donec'k: DonNUET, vol. 29, pp. 73-79.

8. Olijnik O. R. Mizhnarodnij dosvid rozvitku social'noi vidpovidal'nosti ta mozhlivist' jogo zastosuvannya v Ukraïni. URL: http://nbuv.gov.ua/UJRN/inek_2015_4_7 (accessed 20 November 2020).

9. Pirozhenko N. Fenomen social'noi vidpovidal'nosti biznesu: teoretichnij ta istorichnij aspekti. URL: http://www.nbuv.gov.ua/portal/Soc_Gum/Apdu_o/2009_1/R_2/Pirogenko.pdf (accessed 20 November 2020).

10.Social'na vidpovidal'nist': teoriya $\overline{\mathrm{i}}$ praktika rozvitku: monografiya (2012) / A. M. Kolot ta in.; za nauk. red. d-ra ekon. nauk, prof. A. M. Kolota. Kyiv: KNEU, 501 p.

11. Suprun N. A. (2013) Konceptual'ni zasadi korporativnoï social'noi vidpovidal'nosti. Korporativna social'na vidpovidal'nist' biznesu ta osviti: dosvid ta problemi rozvitku: LI UARMBO-2013. Cherkasi, p. 43. 